\title{
KAJIAN KARAKTERISTIK DAS UNTUK DAERAH TANGKAPAN HUJAN WADUK SERMO KABUPATEN KULON PROGO, DAERAH ISTIMEWA YOGYAKARTA
}

\section{Study of Characteristic Watershed for the Catchment of Sermo Reservoir in Kulon Progo Regency, D.I Yogyakarta}

\author{
Silta Yulan Nifen ${ }^{1}$, Bambang Agus Kironoto ${ }^{2}$, Djoko Luknanto ${ }^{3}$ \\ ${ }^{1}$ Jurusan Teknik Sipil, Fakultas Teknik Sipil dan Perencanaan, Institut Teknologi Padang, Indonesia \\ Alamat korespondensi: \\ email: yulansilta@yahoo.com \\ 2,3 Jurusan Teknik Sipil dan Lingkungan, Fakultas Teknik, Universitas Gadjah Mada, Indonesia \\ Alamat korespondensi: \\ email: kironoto12117@gmail.com ; luknanto@ugm.ac.id
}

\begin{abstract}
Human has an important role on the watershed. Every human activity is very influential on the watershed, either directly or indirectly. Characteristic management of watershed for rain catchment area at Sermo Reservoir uses a software of Arc. GIS 10.1. Parameter Bifurcation Ratio rain catchment area at Sermo Reservoir obtaneid $B_{r}<3$ which means the river channel has a flood water rise rapidly while slowdown, calculation of current density value $\left(D_{d}\right)$ rain catchment area at Sermo Reservoir is $1,86 \mathrm{~km} / \mathrm{km}^{2}$ classified means the condition of the substrate material which is impermeable water with medium vegetation. For the Index CN rain catchment area at Sermo Reservoir obtained 81,3 which means high surface flow potential, high clay content and low permeability.
\end{abstract}

Keywords: Watershed, Catchment of Rain, Sermo Reservoir

\begin{abstract}
Abstrak
Manusia memiliki peran penting terhadap suatu Daerah Aliran Sungai (DAS). Setiap aktivitas yang dilakukan manusia sangat berpengaruh terhadap DAS, baik secara langsung maupun tidak langsug. Pengolahan Karakterisitik DAS untuk DTH Waduk Sermo menggunakan software Arc.GIS 10.1. Parameter Bifurcation Ratio DTH Waduk Sermo diperoleh $\mathrm{B}_{\mathrm{r}}<3$ yang berarti alur sungai mempunyai kenaikan muka air banjir dengan cepat sedangkan penurunnya lambat, perhitungan nilai kerapatan aliran $\left(D_{d}\right)$ DTH Waduk Sermo yaitu $1,86 \mathrm{~km} / \mathrm{km}^{2}$ tergolong sedang berarti kondisi material bawah permukaannya kedap air dengan vegetasi yang sedang. Untuk Indeks CN DTH Waduk Sermo memperoleh 81,3 yang berarti potensi aliran permukaan tinggi, kandungan liat tinggi dan permeabilitas rendah.
\end{abstract}

Kata kunci: DAS, Daerah Tangkapan Hujan, Waduk Sermo

\section{PENDAHULUAN}

Manusia memiliki peran penting terhadap suatu Daerah Aliran Sungai (DAS). Setiap aktivitas yang dilakukan manusia sangat berpengaruh terhadap DAS, baik secara langsung maupun tidak langsung.

Berdasarkan data dari Pusat Penelitian Tanah dan Agroklimat, Badan Penelitian dan Pengembangan Pertanian (2005) dalam Penanganan Lahan Kritis dan Sumber Daya Air Berbasis Masyarakat (PLKDA-BM) (2013) menunjukkan bahwa luas lahan kritis di Indonesia mencapai 52,5 juta hektar, dengan rincian untuk pulau Jawa dan Bali seluas 13,52\%, pulau Sumatera sekitar 9,14\%, Kalimantan sekitar 14,09\%, Sulawesi sekitar 9,71\%, Maluku dan Nusa Tenggara sekitar $11,81 \%$, serta Papua sekitar 22,48\%. Permasalahan lahan kritis akan menyebabkan terjadinya erosi dan pendangkalan aliran sungai.

Suharno dalam Kusumandari (1999) menyebutkan lahan kritis yang terjadi di subDAS Ngrancah sudah dalam kondisi yang mengkhawatirkan. Ditandai dengan keadaan kualitas lahan yang buruk sebesar $85,17 \%$ dari luas sub-DAS Ngrancah termasuk dalam 
kategori kualitas buruk sampai sangat buruk. Keadaan ini disebabkan karena tingkat bahaya erosi terjadi sebesar $77 \%$ dari luas sub-DAS yang termasuk dalam golongan berat sampai sangat berat.

Aktivitas masyarakat rata-rata di daerah hulu sub-DAS Ngrancah adalah bercocok tanam dengan didominasi kebun campur dan tegalan. Selain itu, kondisi topografinya yang memiliki kemiringan lereng lumayan curam membuat kondisi tanah di sub-DAS menjadi lebih mudah untuk tererosi ketika terjadinya hujan.

Beberapa penelitian yang dilakukan di sub-DAS Ngrancah maupun Waduk Sermo diantaranya Kusumandari (2012) menyebutkan bahwa kondisi sub-DAS Ngrancah saat ini sudah mengkhawatirkan. Hal ini disebabkan karena pemilihan penggunaan lahan yang tidak sesuai dengan kapasitas dan daya dukung lahan.

Tujuan dari penelitian yaitu mengetahui karakteristik Daerah Aliran Sungai di Daerah Tangkapan Hujan Waduk Sermo. Penelitian ini lebih dominan dari karakteristik morfometri DAS, sebagai berikut.

- Luas

\section{DAS/Drainage/Watershed/Catchment \\ Area $(A)$}

Pada dasarnya sebuah DAS dibatasi igir/punggung pegunungan dan air hujan mengalir sampai pada satu outlet. Semakin luas DAS maka hasil akhir yang didapatkan akan semakin besar, karena air hujan yang tertangkap dalam DAS tersebut juga semakin banyak. Berikut klasifikasi luas DAS:

Tabel 1. Klasifikasi DAS

\begin{tabular}{lll}
\hline No. & Luas DAS (Ha) & Klasifikasi DAS \\
\hline 1 & 1.500 .000 ke atas & DAS sangat \\
2 & $500.000-<1.500 .000$ & besar \\
3 & $100.000-<500.000$ & DAS besar \\
4 & $10.000-<100.000$ & DAS kecil \\
5 & Kurang dari 10.000 & $\begin{array}{l}\text { DAS sangat } \\
\text { kecil }\end{array}$ \\
\hline
\end{tabular}

Sumber: Pedoman Identifikasi Karakteristik DAS (2013)

- $\quad$ Panjang DAS/Watershed Length $(L)$

Panjang daerah aliran sungai adalah jarak datar dari muara sungai ke arah hulu sepanjang sungai induk. Hardiyanto (2014) menyebutkan bahwa panjang basin merupakan aliran sungai terpanjang diukur dari outlet ke titik sungai terjauh.
- Percabangan Sungai/Bifurcation Ratio $\left(B_{r}\right)$

Susunan sungai dapat mempengaruhi efisiensi sistem drainase serta karakteristik hidrografis dan pola aliran bagi pengelola DAS. Sriyana (2011) menyebutkan bahwa menentukan orde sungai dapat menggunakan metode Strahler yaitu alur sungai paling hulu yang tidak mempunyai cabang disebut dengan orde pertama (orde 1), pertemuan antara orde pertama disebut orde kedua (orde 2), demikian seterusnya sampai pada sungai utama ditandai dengan nomor orde yang paling besar, ilustrasi dapat dilihat pada Gambar 1.

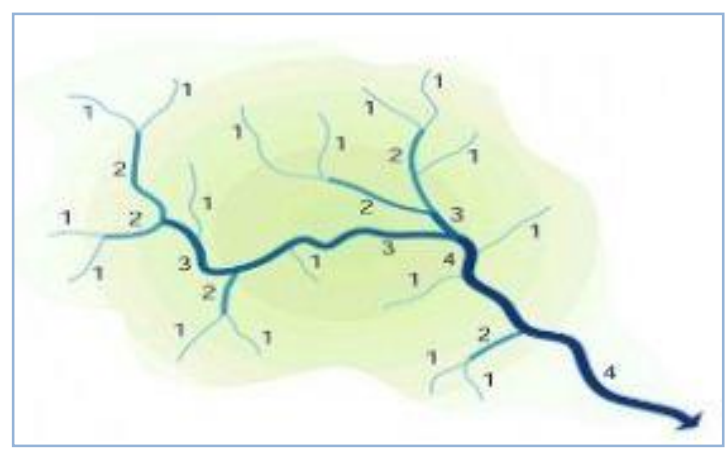

Gambar 1. Menentukan Orde Sungai Metode Strahler

(Sumber: Saputra, 2013)

Orde sungai merupakan posisi percabangan dari alur sungai yang di dalamnya terdapat urutan terhadap sungai utama pada suatu DAS. Serta jumlah alur sungai suatu orde ditentukan dari rasio nisbah percabangan sungai (bifurcation ratio) dengan persamaan:

$$
B_{r}=\frac{N_{u}}{N_{u+1}}
$$

dengan

$B_{r} \quad$ : indeks tingkat percabangan sungai

$N_{u} \quad$ : jumlah alur sungai untuk orde ke-u

$N_{u+1}$ : jumlah alur sungai untuk orde ke$(\mathrm{u}+1)$

Berdasarkan hasil persamaan di atas, maka dapat klasifikasi sebagai berikut:

- $B_{r}<3$ : alur sungai mempunyai kenaikan muka air banjir dengan cepat, sedangkan penurunannya lambat

- Br3-5: maka alur sungai mempunyai kenaikan dan penurunan muka air banjir tidak terlalu cepat atau tidak terlalu lambat 
- $B r>5$ : alur sungai mempunyai kenaikan muka air banjir dengan cepat, demikian pula penurunannya berjalan dengan cepat.

- Pola Aliran

Bentuk pola aliran (drainage pattern) DAS dapat dikelompokkan menjadi 7 (tujuh) diantaranya: dendritik, parallel, radial, trellis, annular, centripetal, dan multibasinal.

- $\quad$ Kerapatan Aliran/Drainage Density $\left(D_{d}\right)$ Pedoman Identifikasi Karakteristik DAS (2013) menjelaskan kerapatan aliran merupakan panjang aliran sungai per kilometer persegi luas DAS:

$$
D_{d}=\frac{\Sigma L_{n}}{A}
$$

dengan

$D_{d} \quad$ : kerapatan aliran $\left(\mathrm{km} / \mathrm{km}^{2}\right)$

$L_{n} \quad$ : panjang sungai $(\mathrm{km})$

A : luas DAS $\left(\mathrm{km}^{2}\right)$

Apabila nilai $D_{d}$ besar, maka semakin baik sistem drainase di daerah tersebut, maksudnya semakin besar jumlah air permukaan total (menyebabkan infiltrasi kecil) maka semakin kecil air tanah yang tersimpan di daerah tersebut. Sriyana (2013) menyebutkan indeks kerapatan aliran sungai dapat diklasifikasi menjadi:

1. $D_{d}:<0,25 \mathrm{~km} / \mathrm{km}^{2}$ : rendah

2. $D_{d}: 0,25-10 \mathrm{~km} / \mathrm{km}^{2}$ : sedang

3. $D_{d}: 10-25 \mathrm{~km} / \mathrm{km}^{2}$ : tinggi

4. $D_{d}:>25 \mathrm{~km} / \mathrm{km}^{2}$ : sangat tinggi

- Profil Sungai Utama

Gabungan dari beberapa anak sungai akan membentuk sungai utama, cara menentukan sungai utama menurut Horton dalam Pedoman Identifikasi Karakteristik DAS (2013) yaitu:

1) jika sudut sungai sama, maka pilihlah sungai yang lebih panjang,

2) jika sudut tidak sama, maka pilihlah sudut yang kecil.

- Gradien Sungai

Gradien sungai yaitu perbandingan beda elevasi dengan panjang sungai utama. Sriyana (2011) parameter ini dapat menunjukkan tingkat kecuraman sungai, jadi semakin besar kecuraman sungai maka semakin tinggi kecepatan aliran airnya. Untuk memperkirakan gradien sungai menggunakan persamaan:

$$
S_{u}=\frac{\left(h_{85}-h_{10}\right)}{0,75 L_{b}}
$$

dengan

$S_{u}$ : gradien sungai/ kemiringan sungai

$h_{85}$ : elevasi pada titik sejauh $85 \%$ dari outlet DAS

$h_{10}$ : elevasi pada titik sejauh $10 \%$ dari outlet DAS

$L_{b} \quad$ : panjang sungai utama

- $\quad$ Perbedaan tinggi DAS $\left(R_{b}\right)$

Keragaman ketinggian dan elevasi rata di suatu DAS termasuk faktor penting dapat berpengaruh terhadap pola hujan dan temperatur terutama pada daerah-daerah yang memiliki topografi yang berbukit atau bergunung (Pedoman Identifikasi Karakteristik DAS, 2013). Sejalan dengan itu, Relief Basin merupakan perbedaan elevasi antara titik tertinggi dan terendah dalam suatu DAS (Hardiyanto, 2014).

\section{METODE PENELITIAN}

Lokasi penelitian yaitu di DTH Waduk Sermo terletak di Kali Ngrancah, Dusun Sermo, Desa Hargowilis, Kecamatan Kokap, Kabupaten Kulon Progo, Provinsi Daerah Istimewa Yogyakarta (Gambar 1).

Data-data yang digunakan dalam penelitian sebagai berikut:

- peta Daerah Tangkapan Hujan (DTH) Waduk Sermo. (Sumber: BPSDA Provinsi DIY)

- peta Jenis Tanah DTH Waduk Sermo. (Sumber: BBWS Serayu-Opak DI.Yogyakarta)

- peta Kontur DTH Waduk Sermo. (Sumber: BBWS Serayu-Opak DI.Yogyakarta)

- peta penggunaan lahan kawasan DTH Waduk Sermo. (Sumber: Google Earth perekaman pada 9 September 2013)

- data spasial sungai DTH Waduk Sermo 


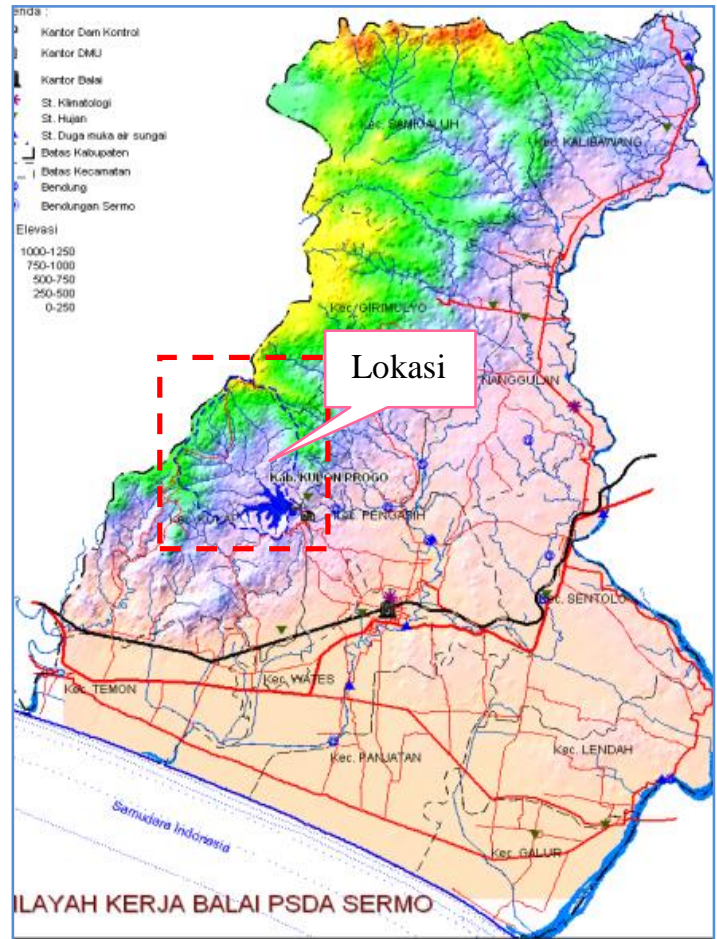

Gambar 1. Lokasi penelitian

Karena menggunakan GIS maka data terdiri dari dua jenis yaitu data spasial dan data atribut, selain itu juga data Parameter Karakteristik DTH Waduk Sermo diantaranya Luas Basin/DAS $(A)$, Relief Basin $\left(R_{b}\right)$, Panjang Basin $(L), \quad$ Bifurcation Ratio/Percabangan Sungai $\left(B_{r}\right)$, Drainage Density $\left(D_{d}\right)$, Slope sungai utama $\left(S_{L P}\right)$, Indeks SCS Curve Number $(C N)$, Persentase Hutan dan $\operatorname{Sawah}\left(F_{L}\right.$ dan $\left.F_{W}\right)$.

Dalam menghitung Parameter Karakteristik DTH Waduk Sermo semuanya menggunakan Software Arc. GIS 10.1. Berikut penjelasan perhitungan parameter karakteristik DTH Waduk Sermo.

- $\quad$ Luas Basin/DAS $(A)$

Menghitung luas Basin/DAS dapat diperoleh berdasarkan dari peta DTH Waduk Sermo.

- $\quad$ Relief Basin $\left(R_{b}\right)$

Relief basin/perbedaan elevasi DAS dihitung berdasarkan peta DEM, maka dapat diperoleh elevasi tertinggi dan terendah untuk DTH Waduk Sermo.

- $\quad$ Panjang Basin $(L)$

Panjang basin dapat dihitung berdasarkan panjang sungai utama yang masuk ke Waduk
Sermo. Untuk sungai utama dapat diperoleh berdasarkan peta.

- Bifurcation Ratio/Percabangan Sungai

$\left(B_{r}\right)$

Bifurcation Ratio dihitung berdasarkan peta sungai dengan cara memberi nomor urut pada masing-masing sungai dimulai dari sungai paling hulu dan diberi nomor urut 1 . Pertemuan antara sungai dengan nomor urut 1 maka sungai tersebut diberi nomor urut 2 . Kemudian pertemuan sungai dengan nomor urut 2 sungai diberi nomor urut 3 dan seterusnya. Per masing-masing sungai yang telah diberi nomor urut maka dijumlahkan serta dimasukkan pada Pers. (3.30).

- $\quad$ Drainage Density $\left(D_{d}\right)$

Drainage Density/kerapatan aliran sungai dapat dihitung dari total panjang jaringan sungai dibagi dengan luas DTH Waduk Sermo.

- $\quad$ Slope sungai utama $\left(S_{L P}\right)$

Kemiringan sungai utama dapat dapat ditentukan dari peta sungai dan peta $D E M$. Dari hasil olahan dengan software Arc.GIS maka dapat diperoleh elevasi sungai utama paling hulu dan elevasi sungai paling hilir. Setelah itu maka dibandingkan antara perbedaan elevasi yang paling hulu dan paling hilir dengan panjang sungai utama.

- Indeks SCS Curve Number (CN)

Untuk menentukan Indeks SCS Curve Number dapat menggunakan peta penggunaan lahan dan peta jenis tanah pada DTH Waduk Sermo. Penentuan Indeks SCS Curve Number berdasarkan Indeks SCS CN (US SCS, 1972 dalam Hardiyanto, 2014)

- $\quad$ Persentase Hutan dan Sawah $\left(F_{L}\right.$ dan $\left.F_{W}\right)$ Persentase hutan dan sawah dapat ditentukan berdasarkan persentase luasan penggunaan lahan yaitu hutan dan sawah. Persentase hutan dan sawah dapat dihitung dengan jumlah luas masing-masing penggunaan lahan dibagi total luas penggunaan lahan dikalikan $100 \%$.

\section{HASIL DAN PEMBAHASAN}

- $\quad$ Luas Basin $(A)$

Berdasarkan dari pengolahan data menggunakan peta DTH Waduk Sermo, maka diperoleh luas basin untuk DTH Waduk 
Sermo seluas 1943,18 ha atau $19,43 \mathrm{~km}^{2}$. Hasil yang diperoleh tidak akan pernah sama persis dengan hasil perhitungan dari penelitian lainnya karena perbedaan peta, digitasi peta dan lainnya tapi hasil yang didapat berkemungkinan mendekati sama.

- $\quad$ Relief Basin $\left(R_{b}\right)$

Berdasarkan dari pengolahan dan perhitungan menggunakan peta DEM (Digitasi Elevation Model) pada Gambar 2. Nilai relief basin yang diperoleh untuk DTH Waduk Sermo yaitu dengan elevasi tertinggi pada $+825 \mathrm{~m}$ dan elevasi terendah pada $+100 \mathrm{~m}$ sehingga nilai relief basin $(+824)-(+100)=+725 \mathrm{~m}$.

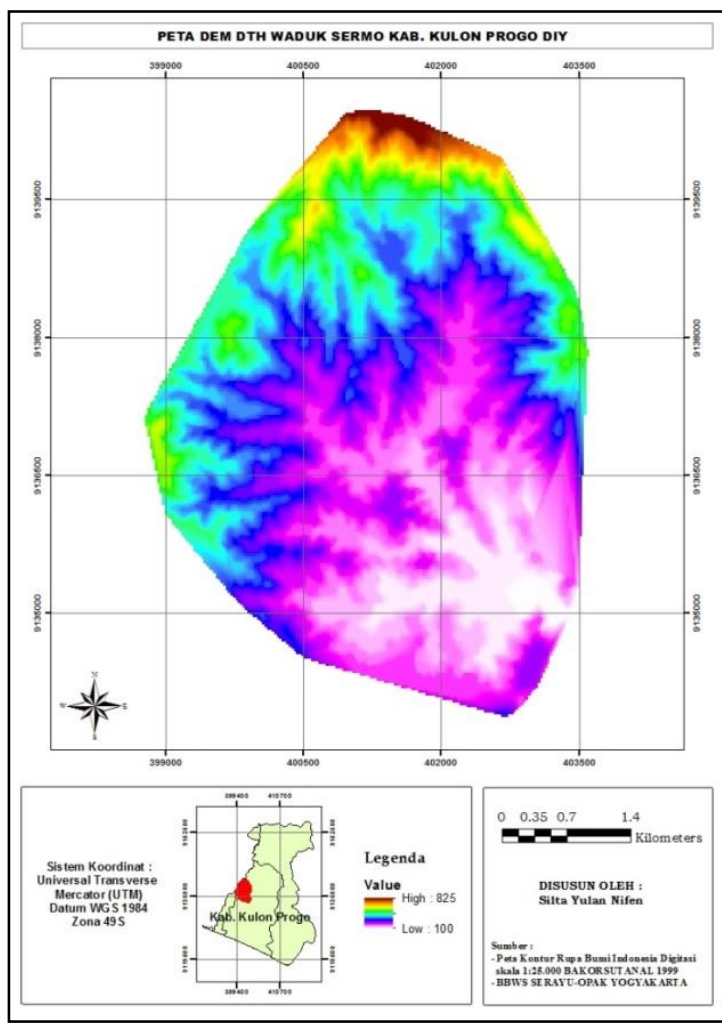

Gambar 2. Peta DEM

- $\quad$ Panjang Basin $(L)$

Panjang basin merupakan panjang sungai terpanjang/sungai utama dapat ditentukan berdasarkan peta sungai (Gambar 3.). Hasil perhitungan diperoleh panjang basin di DTH Waduk Sermo sepanjang 8,93 km.

- Bifurcation Ratio/Percabangan Sungai $\left(B_{r}\right)$

Berdasarkan dari peta sungai yang telah ditentukan urutan ordenya maka nilai $\mathrm{Br}$ (percabangan sungai) diperoleh dengan menggunakan Pers. (1). Hasil perhitungan nilai $B_{r}$ disajikan pada Tabel 2.

Tabel 2. Perhitungan Bifurcation Ratio

\begin{tabular}{ccc}
\hline Orde & Jumlah Alur $\left(\mathrm{N}_{\mathrm{i}}\right)$ & $B_{r}$ \\
\hline 1 & 26 & 3,25 \\
2 & 8 & 2,67 \\
3 & 3 & 3,00 \\
4 & 1 & - \\
\hline & Rata-rata $B_{r}$ & 2,97 \\
\hline
\end{tabular}

Dari tabel hasil perhitungan di atas, diperoleh rata-rata $B_{r}$ sebesar 2,97, jumlah alur paling banyak pada orde 1 sebanyak 26 sungai, sedangkan jumlah alur paling sedikit pada orde 4 sebanyak 1 sungai.

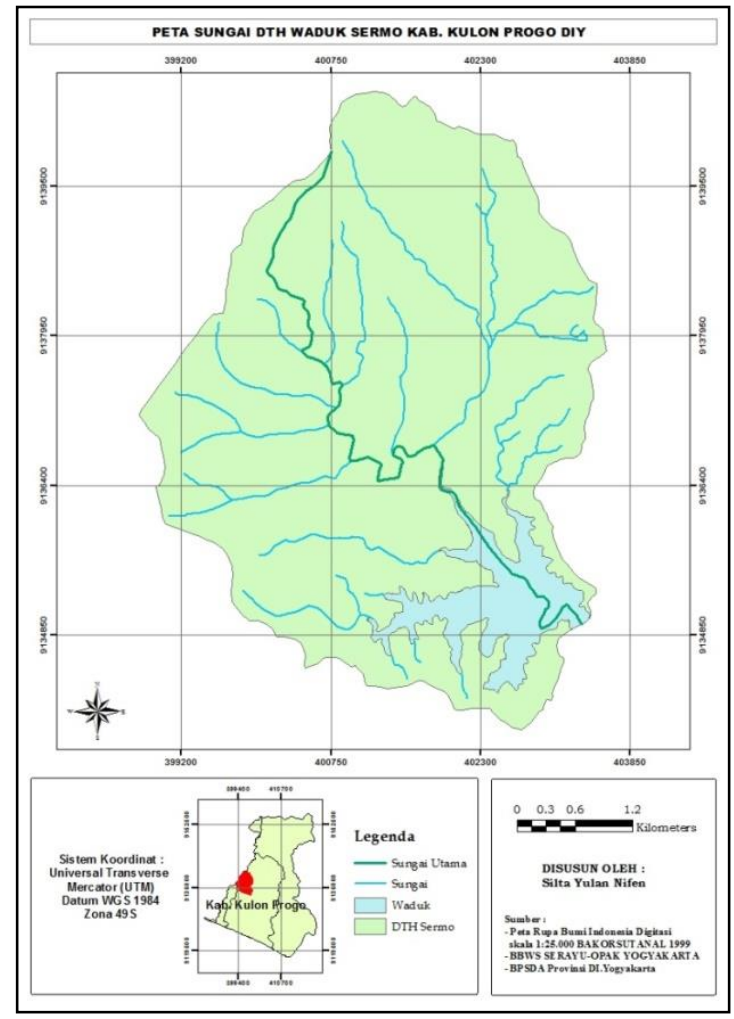

Gambar 3. Peta Sungai

- $\quad$ Drainage Density $\left(D_{d}\right)$

Nilai $D_{d}$ (kerapatan aliran sungai) diperoleh berdasarkan peta sungai. Untuk menghitung nilai $D_{d}$ maka harus diketahui panjang jaringan sungai dan luas DAS/DTH. Panjang jaringan sungai merupakan total panjang jaringan sungai yang ada di DTH Waduk Sermo, diperoleh sepanjang 36,21 km. sedangkan luas DAS sebesar 19,43 $\mathrm{km}^{2}$. Untuk memperoleh nilai $D_{d}$ dihitung dengan cara membagi total panjang jaringan sungai 
dengan luas DTH Waduk Sermo, maka hasil yang diperoleh untuk nilai kerapatan sungai yaitu $1,86 \mathrm{~km} / \mathrm{km}^{2}$.

- $\quad$ Slope sungai utama $\left(S_{L P}\right)$

Nilai $S_{L P}$ diperoleh berdasarkan dari peta sungai dan peta $D E M$ dengan cara mengetahui elevasi sungai utama paling hulu dan elevasi sungai utama paling hilir dan mengetahui panjang sungai utama. Dari hasil perhitungan maka diperoleh elevasi sungai utama paling hulu berada pada ketinggian $+600 \mathrm{~m}$ dan elevasi sungai utama paling hilir berada pada ketinggian $+100 \mathrm{~m}$ sedangkan panjang sungai utama yaitu sepanjang $8,93 \mathrm{~km}$ maka nilai $S_{L P}$ yaitu perbedaan elevasi sungai utama dibagi dengan panjang sungai utama. $S_{L P}=\left(\frac{(+600)-(+100)}{8,93 \times 1000}\right) \times 100=5,60 \%$

- Indeks SCS Curve Number (CN)

Dengan menggunakan Peta Penggunaan Lahan (Gambar 4.) dan Peta Jenis Tanah (Gambar 5.) setelah dioverlay maka dapat ditentukan dan diperoleh Peta Indeks $C N$ untuk DTH Waduk Sermo seperti yang disajikan pada Gambar 6. Nilai Indeks SCS Curve Number diperoleh dari hasil rerata nilai $C N$ yang telah dioverlay sebesar 81,3.

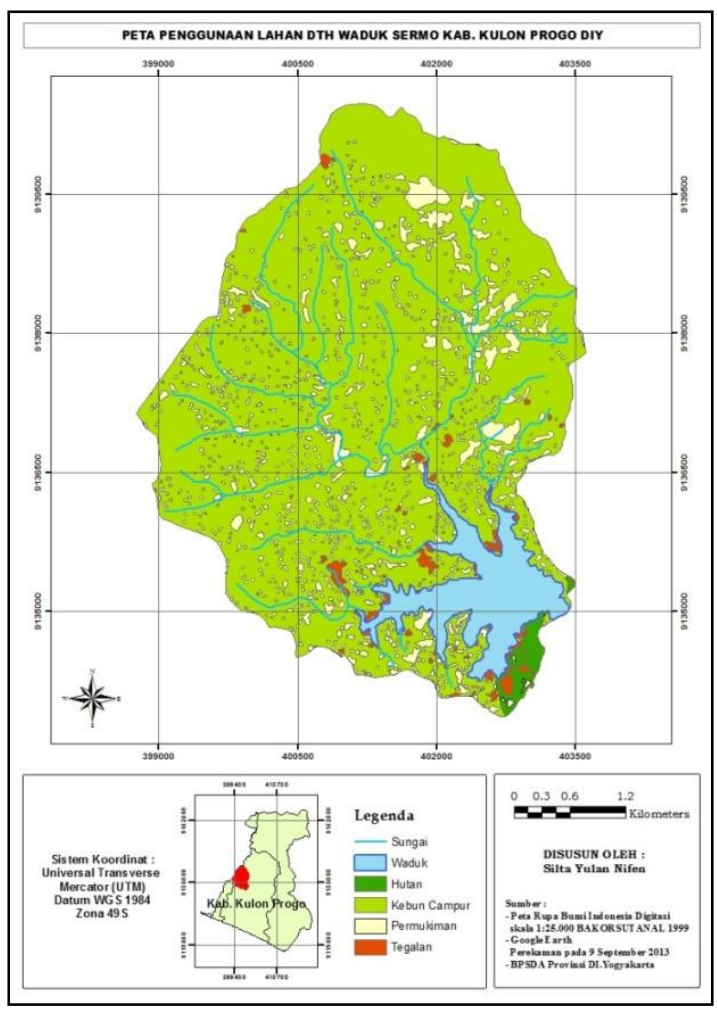

Gambar 4. Peta Penggunaan Lahan

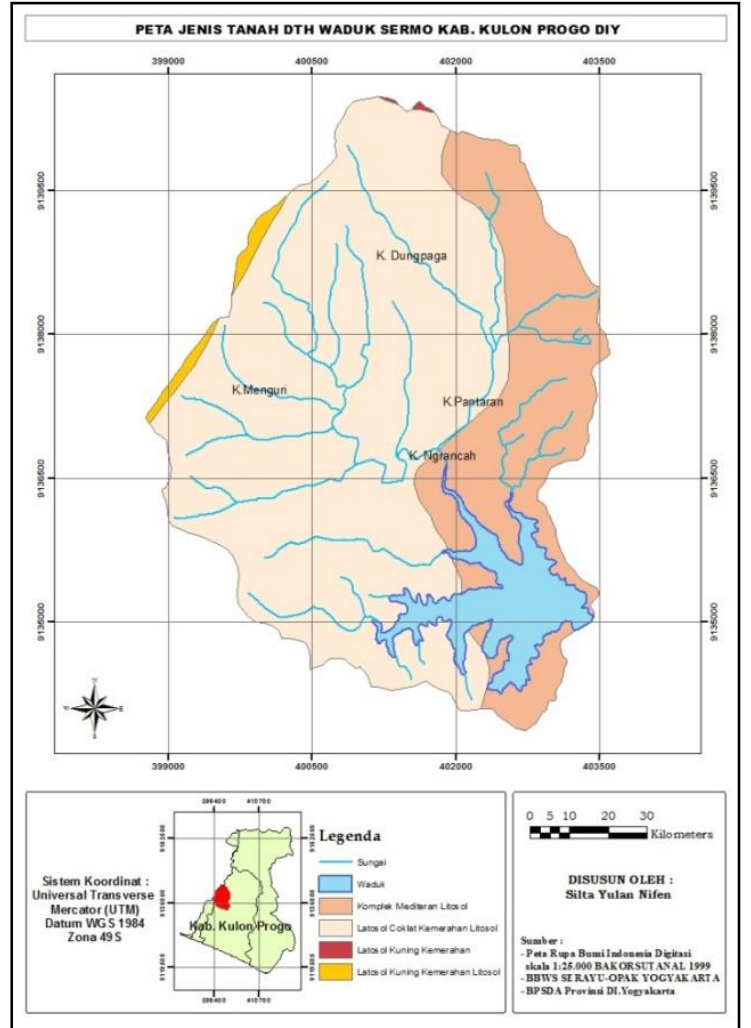

Gambar 5. Peta Jenis Tanah

Hasil perhitungan Karakteristik DAS untuk DTH Waduk Sermo dapat direkapitulasikan pada Tabel 3.

Tabel 3. Rekapitulasi Karakteristik DAS untuk DTH Waduk Sermo

\begin{tabular}{clccc}
\hline No & \multicolumn{1}{c}{ Parameter } & Simbol & Nilai & Satuan \\
\hline 1 & Luas Basin & $A$ & 19,43 & $\mathrm{~km}^{2}$ \\
2 & Relief basin & $R_{b}$ & 725 & $\mathrm{~m}$ \\
3 & Panjang Basin & $L$ & 8,93 & $\mathrm{~km}$ \\
4 & Bifurcation ratio & $B_{r}$ & 2,97 & - \\
5 & Drainage density & $D_{d}$ & 1,86 & $\mathrm{~km} / \mathrm{km}^{2}$ \\
6 & Slope Sungai & $S_{L P}$ & 5,69 & $\%$ \\
& utama & & & \\
7 & Indeks SCS Curve & $C N$ & 81,3 & - \\
& Number & & 1,22 & $\%$ \\
8 & Persentase Hutan & $F_{L}$ & 0 & $\%$ \\
9 & Persentase Sawah & $F_{W}$ & 0 & \\
\hline
\end{tabular}

Dari Tabel 3. menunjukkan bahwa luas basin pada DTH Sermo termasuk klasifikasi DAS sangat kecil, dari parameter Bifurcation Ratio DTH Waduk Sermo diperoleh $B_{r}<3$ yang berarti alur sungai mempunyai kenaikan muka air banjir dengan cepat sedangkan penurunnya lambat, berdasarkan dari perhitungan nilai kerapatan aliran $\left(D_{d}\right)$ 
DTH Waduk Sermo yaitu $1,86 \mathrm{~km} / \mathrm{km}^{2}$ tergolong sedang berarti kondisi material bawah permukaannya kedap air dengan vegetasi yang sedang. Untuk parameter Indeks SCS CN DTH Waduk Sermo memperoleh 81,3 yang berarti potensi aliran permukaan tinggi, kandungan liat tinggi dan permeabilitas rendah.

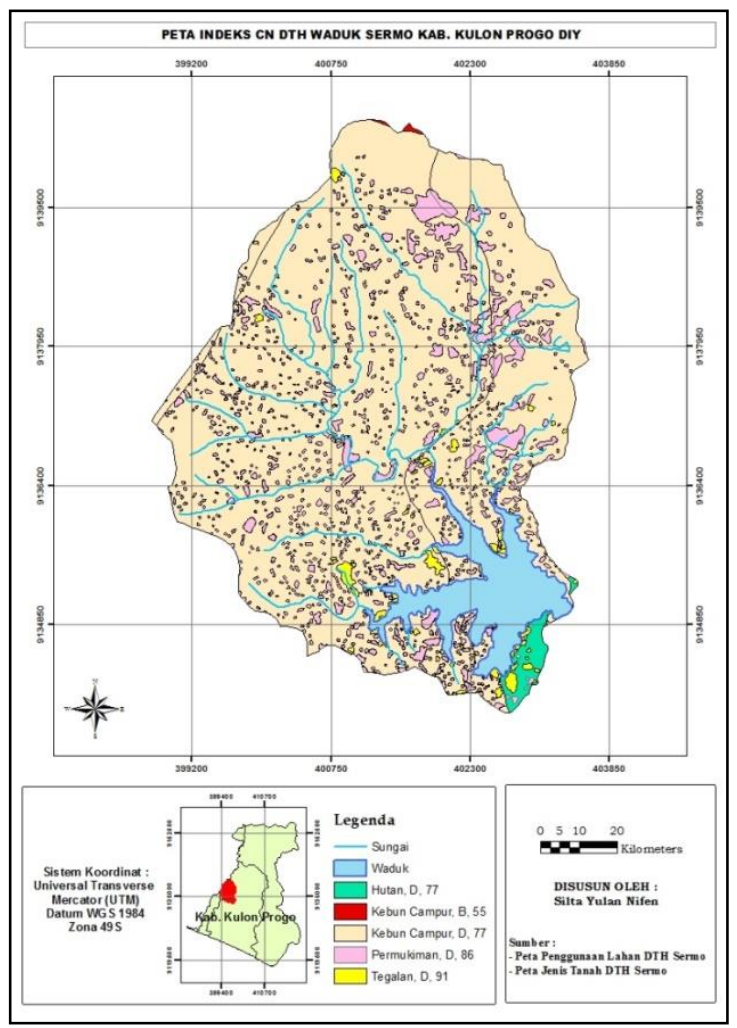

Gambar 6. Peta Indeks CN

\section{KESIMPULAN}

- parameter Karakterisitik DAS untuk DTH Waduk Sermo yaitu luas basin pada DTH Sermo termasuk klasifikasi DAS sangat kecil,

- $\quad$ parameter Bifurcation Ratio DTH Waduk Sermo diperoleh $B_{r}<3$ yang berarti alur sungai mempunyai kenaikan muka air banjir dengan cepat sedangkan penurunnya lambat,

- $\quad$ nilai kerapatan aliran $\left(D_{d}\right)$ DTH Waduk Sermo yaitu $1,86 \mathrm{~km} / \mathrm{km}^{2}$ tergolong sedang berarti kondisi material bawah permukaannya kedap air dengan vegetasi yang sedang.

- Indeks SCS CN DTH Waduk Sermo memperoleh 81,3 yang berarti potensi aliran permukaan tinggi, kandungan liat tinggi dan permeabilitas rendah.

\section{DAFTAR PUSTAKA}

Arsyad, Sitanala., 2012. Konservasi Tanah dan Air. Bogor: IPB Press.

Asdak, Chay., 2010. Hidrologi dan Pengelolaan Daerah Aliran Sungai. Yogyakarta : Gadjah Mada University Press.

Danoedoro, Projo., 2012. Pengantar Penginderaan Jauh Digital. Yogyakarta: Andi Offset.

Hardiyanto, D.I., 2014, Kajian Sediment Delivery Ratio di Daerah Tangkapan Waduk Kedung Ombo. Tesis. Magister Pengelolaan Bencana Alam. Universitas Gadjah Mada.

Kartasapoetra., 2010. Teknologi Konservasi Tanah dan Air. Jakarta: Rineka Cipta.

Kementerian Kehutanan, 2009. Tata Cara Penyusunan Rencana Teknik Rehabilitasi Hutan dan Lahan Daerah Aliran Sungai (RTkRHL$D A S)$, Jakarta.

Kementerian Kehutanan, 2013. Pedoman Identifikasi Karakteristik Daerah Aliran Sungai, Jakarta.

Kironoto, BA dan Yulistiyanto, B., 2000. Konservasi Lahan. Yogyakarta: Universitas Gadjah Mada.

Kusumandari, Ambar., 2012, Penanganan Konservasi Tanah dan Air Berbasis Unit Ekologis di sub-DAS Ngrancah, Kulon Progo. Disertasi. Jurusan Ilmu Kehutanan. Univesitas Gadjah Mada.

Setiawan, Sigit., 2010, Kajian Sedimentasi Waduk Berdasarkan Kondisi Tataguna Lahan: Studi Kasus Waduk Sermo Kabupaten Kulon Progo, Provinsi Daerah Istimewa Yogyakarta. Tesis. Magister Pengelolaan Bencana Alam (MPBA). Univesitas Gadjah Mada.

Sriyana, 2011, Kajian Karakteristik DAS Tuntang dan Model Pengelolaan DAS Terpadu, TEKNIK - Vol.32 No.3, ISSN 0852-1697.

Suripin, 2004. Pelestarian Sumber Daya Tanah dan Air Pendidikan. Yogyakarta: Penerbit Andi. 